\title{
PENINGKATAN KREATIVITAS MAHASISWA PGSD ANGKATAN 2018 DALAM MENDESAIN RPP K-13 MENGGUNAKAN PENDEKATAN CTL PADA TAHUN 2018 TEBUIRENG-JOMBANG
}

\author{
M. Bambang Edi Siswanto \\ Prodi PGSD, Fakultas Ilmu Pendidikan Universitas Hasyim Asy'ari \\ mbambangedi@gmail.com
}

\begin{abstract}
Abstrak
Belajar merupakan suatu proses perubahan kegiatan dan reaksi terhadap lingkungan. Perubahan kegiatan yang dimaksud mencakup pengetahuan, kecakapan dan tingkah laku. Perubahan itu diperoleh melalui pengalaman (latihan) bukan dengan sendirinya berubah karena kematangan atau keadaan sementara. Adapun tujuan penelitian ini adalah untuk mengetahui peningkatan menyusun RPP dengan menggunakan pendekatan Contekstual Teaching And Learning (CTL) bagi mahasiswa PGSD angkatan 2018 Peningkatan tersebut diharapkan terjadi pada tahap-tahap menyusun dimulai pramenyusun, Saat menyusun dan pasca menyusun RPP. Metode penelitian yang digunakan adalah deskriptif kualitatif dengan menggunkan rancangan penelitian tindakan, yang disusun dalam satuan siklus dengan sistem berulang. Setiap siklus berisi aktivitas pembelajaran pramenyusun, saat menyusun, dan pasca menyusun melalui perencanaan, pelaksanaan, observasi dan refleksi. Hasil refleksi digunakan sebagai dasar untuk perbaikan pembelajaran pada siklus berikutnya. Data penelitian diperoleh dari hasil pengamatan, catatan lapangan, dan dokumentasi. Hasil penelitian menunjukan adanya peningkatan kreativitas penyusunan RPP pada mahasiswa PGSD angkatan 2018. Peningkatan kreativitas penyusunan pramenyusun RPP tercermin pada semakin tepat mengidentifikasi dan memahami struktur RPP. Pada saat menyusun RPP kemampuan mahasiswa meningkat. Peningkatan tersebut tercermin dalam penggunaan multistrategi mengajar yang kreatif dan inovatif dan mensimulasikan didepan kelas.
\end{abstract}

Kata kunci: Perencanaan pembelajaran, Pendekatan CTL dan Struktur RPP

\begin{abstract}
Learning is a process of changing activities and reactions to the environment. Changes in activities in question include knowledge, skills and behavior. The change obtained through experience (practice) does not automatically change due to maturity or temporary circumstances. The purpose of this research is to find out the improvement of drafting lesson plans by using the Teaching And Learning Contextual Approach (CTL) for the 2018 class of PGSD students. The increase is expected to occur in the stages of arranging the preparation of the preparers. The research method used is descriptive qualitative by using an action research design, which is arranged in cycles with repeated systems. Each cycle contains pre-composing learning activities, when compiling, and post-compiling through planning, implementation, observation and reflection. The results of reflection are used as a basis for improving learning in the next cycle. The research data was obtained from observations, field notes, and documentation. The results showed an increase in the creativity of RPP preparation for the 2018 PGSD students. Increased creativity in the preparation of lesson plans was reflected in the more precisely identifying and understanding the RPP structure. At the time of preparing the RPP the ability of students to increase. This increase was reflected in the use of creative and innovative multistrategic teaching and simulating in front of the class.
\end{abstract} Keywords: Learning planning, CTL approach and RPP structure

\section{PENDAHULUAN}

Pendidikan merupakan wacana yang selalu mengalami perubahan dan strategistrategi baru dalam pengembangannya ke depan. Pendidikan merupakan kunci utama kemajuan dan peradaban suatu bangsa, semakin baik kualitas pendidikan yang diselenggarakan oleh suatu masyarakat/bangsa, maka secara tidak langsung akan merubah pemikiran masyarakat/bangsa itu sendiri. 
Dalam pengertian yang luas, pendidikan dapat diartikan sebagai sebuah proses dengan strategi-strategi tertentu sehingga orang memperoleh pengetahuan, pemahaman, dan cara tingkah laku yang sesuai dengan kebutuhan. Pendidikan adalah usaha sadar yang dilakukan untuk menyiapkan peserta didik melalui kegiatan bimbingan, pengajaran dan atau latihan agar peserta didik tersebut berperan dalam kehidupan masa depannya.

Belajar merupakan suatu proses pembentukan pengetahuan, yang mana siswa aktif melakukan kegiatan, aktif berfikir, menyusun konsep, dan memberi makna aktif melakukan kegiatan, aktif berfikir, menyusun konsep, dan memberi makna tentang hal-hal yang sedang dipelajari (Budiningsih, 2005:58).

Dengan demikian, belajar merupakan suatu proses usaha yang dilakukan individu secara sadar untuk memperoleh perubahan tingkah laku tertentu, baik yang dapat diamati secara langsung atau tidak dapat diamati secara langsung sebagai pengalaman (latihan) dalam interaksinya dengan lingkungan. Dapat dikatakan juga bahwa belajar sebagai aktivitas mental atau psikis yang berlangsung dalam interaksi aktif dengan lingkungan dan menghasilkan perubahan dalam pengetahuan dan pemahaman, keterampilan serta nilai-nilai, dan sikap.

Dalam proses pembelajaran di kelas mengalami kendala dalam hal mendesain RPP. Hal ini terungkap saat mengobservasi keterlibatan siswa dalam memahami ruh dalam menyusun RPP, penulis mendapati kondisi siswa yang cenderung hanya copy paste dari buku guru untuk dijadikan RPP tanpa adanya kreasi dari mahasiswa. Dari kondisi tersebut maka perlu adanya kreativitas mahasiswa dengan mengajarkan beberapa srategi mengajar sehingga mampu mengkreatifkan RPP yang inovatif melalui kegiatan pembelajaran CTL.

Berdasarkan kondisi di atas penulis berkolaborasi dengan dosen PGSD untuk melaksanakan penelitian tindakan kelas. Penelitian dilakukan sebagai upaya untuk memperbaiki kualitas mata kuliah perencanaan pembelajaran dalam menyusun RPP. Adapun tindakan yang dilakukan yaitu "peningkatan kreativitas mendesain RPP dengan menggunakan pendekatan pembelajaran kontekstual bagi mahasiswa PGSD angkatan 2018.

Depdiknas (2002: 26) pendekatan kontekstual merupakan konsep belajar yang membantu mahasiswa antara materi yang dijabarkan dengan situasi dunia nyata kondisi mahasiswa membuat hubungan antara pengetahuan yang dimiliki dengan penerapannya dalam kehidupan mereka sebagai anggota keluarga dan masyarakat. Pengetahuan dan keterampilan mahasiswa diperoleh dari mengkontruksi sendiri pengetahuan dan keterampilan ketika ia belajar. Pendekatan CTL melibatkan tujuh komponen utama pembelajaran produktif yakni kontruktivisme (contruktivism), bertanya (questioning), menemukan (inquiry) masyarakat belajar (learning community), pemodelan (modeling), dan penilaian sebenarnya (authentic assessment).

Dengan konsep ini diharapkan pembelajaran lebih bermakna bagi mahasiswa, proses pembelajaran berlangsung secara alamiah, dalam bentuk kegiatan mahasiswa bekerja dan mengalami, bukan transfer pengetahuan dari dosen ke mahasiswa, strategi pembelajaran lebuh diutamakan dari pada hasil.

Penyusunan RPP dengan menggunakan pendekatan pembelajaran Contextual Teaching And Learning (CTL) mahasiswa dapat menuangkan gagasan dengan penuh senyum sebab obyek persoalannya adalah lingkungan yang alami di sekitar siswa dan secara langsung dapat dijadikan sumber belajar. Lingkungan tersebut akan membangkitkan minat siswa dengan pikiran dan perasaan untuk menuangkan gagasan. Berdasarkan paparan tersebut diperlukan penelitian tindakan kelas dengan Judul "penerapan pendekatan CTL untuk meningkatkan kreativitas mahasiswa PGSD dalam mendesain RPP kurikulum 2018".

\section{METODE}

Metode penelitian sangat dibutuhkan dalam mengadakan penelitian. Dengan 
penelitian yang benar hasil penelitian dapat dipertanggung jawabkan pada bagian ini akan dipaparkan beberapa hal yang berkaitan dengan metode penelitian adalah sebagai berikut : Rancangan penelitian merupakan kerangka data didalam suatu penelitian. Kejelasan rancangan dapat mempengaruhi validitas data dan tingkat kepercayaan hasil penelitian, Penelitian ini merupakan penelitian tindakan kelas dengan menggunakan metode deskriptif kualitatif. Prosedur pelaksanaannya mengikuti prinsip dasar penelitian tindakan kelas. Mengacu pada pandangan Kemmis dan Taggrat (dalam Arikunto, 2008) penelitian tindakan diawali dengan mengidentifikasi gagasan umum yang dispesifikasikan sesuai dengan tema penelitian. Spesifikasi gagasan tersebut lebih lanjut digarap melalui empat tahap secara berdaur ulang yaitu perencanaan, pelaksaan tindakan, pengamatan, dan refleksi. Hal itu dilakukan sebagai rangkaian kegiatan pada siklus pertama.

Berdasarkan hasil refleksi siklus pertama dilakukan perbaikan tindakan pembelajaran pada siklus ke dua. Peneliti merencanakan tindakan siklus ke dua kemudian dilanjutkan dengan pelaksanaan tindakan, pengamatan, dan refleksi. Dari hasil refleksi siklus ke dua kemudian disusun perencanaan berikutnya, pelaksanaan tindakan, pengamatan, dan diakhiri dengan refleksi. Adapun rincian kegiatan pada setiap siklus sebagai berikut:

\section{Siklus I}

\section{Tahap persiapan}

Kegiatan penelitian berupa observasi terhadap pembelajaran pada mahasiswa PGSD angkatan 2018, untuk mengetahui permasalahan yang terjadi dalam pembelajaran khususnya dalam pembuatan RPP. Dari hasil observasi tersebut, peneliti mengadakan penelitian tindakan kelas yang mengambil judul penerapan multi strategi mengajar dalam meningkatkan kreativitas dalam membuat RPP K-13

\section{Tahap perencanaan kegiatan}

Berdasarkan rumusan masalah hasil observasi selanjutnya peneliti melakukan perencanaan tindakan dengan langkah- langlah sebagai berikut: (1) Menyusun rencana perkuliahan dengan menerapkan multistrategi mengajar; (2) Merencanakan prosedur kegiatan pembelajaran perencanaan pembelajaran; Merencanakan alat evaluasi, baik evaluasi proses maupun evaluasi produk; (4) Menyiapkan pedoman pengamatan tentang pelaksanaan pembelajaran mata kuliah perencanaan pembelajaran.

\section{Tahap pelaksanaan tindakan}

Dalam tahap ini merupakan tahap penerapan rencana yang telah di buat . Pelaksanaan tindakan berupa pembelajaran dalam mata kuliah perencanaan pembelajaran, Adapun kegiatan pembelajaran pada siklus pertama ini dapat digambarkan sebagai berikut :

Kegiatan awal

- Guru membuka pelajaran dengan berdoa terlebih dahulu

- Guru memberikan motivasi dalam bentuk alfa zone dan menyampaikan tujuan pembelajaran

Kegiatan inti

- Guru membagi siswa menjadi 3 kelompok (masing-masing kelompok terdiri dari 3 mahasiswa )

- Guru menunjukkan contoh RPP yang sudah jadi untuk di analisis disesuaikan dengan struktur penulisan RPP;

- Guru mengajak kepada mahasiswa untuk melakukan analisis terhadap RPP yang telah dibuat

- Mahasiswa mengisi lembar analisis RPP yang telah disiapkan;

- Dosen mengadakan kegiatan brainstorming dalam kegiatan diskusi berkaitan dengan struktur RPP yang telah pelajari;

- Semua jawaban mahasiswa dibrainstormingkan untuk diambil sebuah kesimpulan

- Dosen memberikan bimbingan seperlunya kepada mahasiswa dalam mengerjakan tugas

- Semua siswa mengumpulkan hasil pekerjaannya tersebut kepada dosen

Kegiatan penutup

- Dosen menyampaikan kesimpulan pembelajaran 
- Selanjutnya menyampaikan cerita hikmah

- Dosen menyampaikan apresiasi kepada para mahasiswa

\section{Tahap pengamatan}

Kegiatan pengamatan ini dilakukan untuk melakukan sesuatu yang berhubungan dengan pelaksanaan kegiatan pembelajaran. Hal-hal yang diamati diantaranya kendala yang dihadapi saat kegiatan pembelajaran berlangsung, masalah-masalah yang terjadi dalam kegiatan pembelajaran yang nantinya akan menjadi acuan dalam siklus kedua

\section{Tahap refleksi}

Permasalahan yang terjadi saat dilakukan kegiatan pembelajaran dianalisis dan dicari pemecahannya. Berdasarkan pelaksanaan kegiatan pembelajaran yang dilakukan, peneliti mengadakan perbaikan atau penyempurnaan pada perencanaan dan pelaksanaan tindakan untuk siklus berikutnya.

\section{Siklus II}

\section{Tahap persiapan}

Pada tahap ini pelaksanaan pembelajaran hampir sama pada siklus I, tetapi pada siklus ke 2 peneliti lebih mengoptimalkan penggunaan strategi mengajar adapun langkah pembelajaran pada tahap ini sebagai berikut: (1) Menyusun perencanaan pelaksanaan pembelajaran perencanaan pembelajaran menggunakan multistrategi; (2) Merancang prosedur kegitan pembelajaran perencanaan pembelajaran menggunakan multistrategi; (3) Merencanakan alat evaluasi baik evaluasi proses maupun evaluasi produk;

(4) Menyiapkan pedoman pengamatan tentang pelaksanaan pembelajaran perencanaan pembelajaran menggunakan multistrategi.

\section{Tahap pelaksanaan tindakan}

Dalam tahap ini merupakan tahap penerapan rencana yang telah di buat . Pelaksanaan tindakan berupa pembelajaran perencanaan pembelajaran yang menerapkan multistrategi mengajar kepada mahasiswa Adapun kegiatan pembelajaran pada siklus kedua ini dapat digambarkan sebagai berikut :

Kegiatan awal

- Guru membuka pelajaran dengan berdoa terlebih dahulu

- Guru memberikan motivasi untuk memunculkan semangat siswa dalam pembelajaran

- Guru menyampaikan tujuan pembelajaran

Kegiatan inti

- Dosen membagi menjadi 3 kelompok setiap kelompok ada 3 mahasiswa

- Dosen menyampaikan scene setting pembelajaran dengan sumber ide asas manfaat dan nilai guna

- Mamhasiswa memilih tema yang akan di yang akan dikreasikan dalam sebuah karya tulis RPP

- Sebagaimana yang telah direncanakan mahasiswa akan menerapkan multi strategi mengajar dan memelih strategi mana yang akan dinilai

- Mahasiswa membuat rublik penilaian dari strategi yang dilakukan

- Setelah mahasiswa menyelesaikan rublik penilaian dan latihan soal

- Menggunakan strategi teaching learning mahasiswa untuk saling pear teaching dengan sesamanya

- Mahasiswa yang di tunjuk sebagai penilai memberikan masukan dan saran yang membangun pada perbaikan

- Dosen mengklarifikasi dari permasalahan yang muncul dalam kegiatan refleksi

- Selanjutnya diadakan kegiatan konfirmasi dalam kegiatan Tanya jawab

Kegiatan penutup

- Dosen menyampaikan kesimpulkan dari kegiatan perkuliahan

- Selanjutnya dengan pemberian apresiasi dan projek dari perbaikan RPP

- Guru menutup pelajaran dengan memberikan pesan moral, berdoa dan salam penutup.

\section{Tahap pengamatan}

Kegiatan pengamatan ini dilakukan untuk melakukan sesuatu yang berhubungan dengan pelaksanaan kegiatan pembelajaran. Hal-hal yang diamati diantaranya kendala yang dihadapi saat 
kegiatan pembelajaran berlangsung, masalah-masalah yang terjadi dalam kegiatan pembelajaran yang nantinya akan menjadi acuan dalam siklus berikutnya jika dipandang perlu.

\section{Tahap refleksi}

Permasalahan yang terjadi saat dilakukan kegiatan pembelajaran dianalisis dan dicari pemecahannya. Berdasarkan pelaksanaan kegiatan pembelajaran yang dilakukan, peneliti mengadakan perbaikan atau penyempurnaan pada perencanaan dan pelaksanaan tindakan untuk siklus berikutnya.

\section{HASIL DAN PEMBAHASAN}

Hasil penelitian peningkatan kreativitas menyusun RPP dengan menggunakan Pendekatan CTL bagi mahasiswa PGSD angkatan 2018. Diuraikan berdasarkan siklus-siklus tindakan pembelajaran. Setiap siklus tindakan pembelajaran diuraikan tentang perencanaan, pelaksanaan pengamatan, dan refleksi.

\section{Hasil penelitian siklus I Perencanaan}

Perencanaan pembelajaran siklus I terlaksanan melalui Rencana Program semester (RPS) yang mencakup komponenkomponen sebagai berikut: waktu, standar kompetensi, kompetensi dasar, indikator dan tujuan pembelajaran, kegiatan pembelajaran, materi, media atau sumber dan evaluasi/penilaian.

Waktu yang direncanakan pada pelaksanaan pembelajaran siklus I terdiri atas satu pertemuan yang dilaksanakan dalam waktu 2 x 50 menit yang diklasifikasikan sebagai berikut: 15 menit untuk kegiata awal, 60 menit untuk kegiatan inti, 15 menit untuk kegiatan kegiatan penutup. Pelaksanaan pembelajaran siklus I dilaksanakan pada hari Ahad, 6 maret 2018.

\section{Tahap pelaksanaan}

Dalam tahap pelaksanaan proses penelitian dibagi menjadi 3 tahap yaitu kegiatan awal pembelajaran (pra menyusun), kegiatan inti pembelajaran(saat penyusunan), kegiatan akhir pembelajaran(pasca menyusun ).

Kegiatan pembelajaran siklus pertama:

Dalam tahap ini merupakan tahap penerapan rencana yang telah di buat . Pelaksanaan tindakan berupa perencanaaan pembelajaran dengan penerapan pendekatan Contekstual Teaching And Learning (CTL) kepada mahasiswa Adapun kegiatan pembelajaran pada siklus pertama ini dapat digambarkan sebagai berikut :

Kegiatan awal

- Guru membuka pelajaran dengan berdoa terlebih dahulu

- Guru memberikan motivasi dan menyampaikan tujuan pembelajaran

- Mengawali kegiatan pembelajaran diadakan kegiatan brain gym.

- Guru membagi siswa menjadi 3 kelompok (masing-masing kelompok terdiri dari 3 mahasiswa)

Kegiatan inti

- Dosen menyampaikan struktur RPP mahasiswa memperhatikan dan mendiskusikan apabila ada yang belum di paham

- Secara berkelompok mahasiswa menganalisis RPP yang telah di buat

- Dengan rublik yang telah dibuat mahasiswa menilai dan memberikan masukan untuk perbaikan

- Dengan bimbingan dosen mahasiswa mendiskusikan hasil revisi yang telah disampaikan oleh sesame temannya

- Dosen mengkonfirmasi pemahaman mahasiswa dari apa yang telah dipahami dan apa yang belum dipahami

Kegiatan penutup (pasca menulis)

- Dosen menyampaikan kesimpulan perkuliahan

- Bersama dengan mahasiswa mengungkap sebuah cerita hikmah

- Dilanjutkan dengan kegiatan apersiasi pembelajaran

- Dosen menugaskan kepada mahasiswa untiuk melaksanakan revisi RPP

Dari media yang digunakan adalah flas card yang berisi potongan dari beberapa unsur yang ada dalam perangkat pembelajaran

Evaluasi/penilaian pada pembelajaran meliputi evaluasi proses dan hasil. Evaluasi 
proses yang dimaksud adalah aktivitas siswa dalam kegiatan perkuliahan sedangkan evaluasi hasil adalah hasil karya siswa dalam bentuk bendel RPP

\section{Refleksi siklus I}

Refleksi pembelajaran meliputi tahap awal, inti dan tahap penutup. Penyampaian tujuan yang dilakukan oleh guru dengan baik. Siswa tampak tenang dan tertarik untuk medengar dan mengikuti pembelajaran, siswa semakin antusias memperhatikan penjelasan dari Dosen tentang materi yang akan diajarkan yaitu menyusun RPP menggunakan pendekatan kontekstual .

Kegiatan yang membangun skemata pengetahuan awal yang dimiliki mahasiswa dari dosen kurang optimal karena ketika dosen mengajak mahasiswa menganalisis RPP yang telah di buatnya masih banyak yang bingung karena mahasiswa belum memahami struktur RPP yang baik dan benar karena masih bingung dengan istilahistilah yang asing bagi para mahasiswa. Sehingga mahasiswa masih asal dalam menilai RPP dari temannya.

Ketika Dosen menjelaskan tentang struktur RPP mahasiswa yang ramai sendiri kurang memperhatikan penjelasan dari dosen karena dalam penjelasan terkesan membosankan dan menjenuhkan, selanjutnya melalui kegiatan tanya jawab, tetapi kegiatan itu masih belum efektif karena

Pada saat dilaksanakannya pengamatan pada obyek/benda yang sudah ditentukan guru pada masing-masing kelompok untuk mencatat hal-hal yang ditemukan ada siswa yang tidak mau kerjasama dalam kelompok dan balum tahu apa yang harus diamati seharusnya guru selalu membimbing dan memberikan penjelasan secara khusus kepada siswa yang bersangkutan.

Pada saat guru meminta siswa menentukan ide/gagasan pokok dan judul puisi berdasarkan hasil pengamatan untuk mengembangkannyan dalam betuk teks puisi yang utuh sesuai unsur-unsur atau struktur puisi siswa belum datapt menentukan dan mengembangkan sesuai ide/gagasan pokok yang ditentukan dari hasil pengamatan. Maka seharusnya guru perlu membimbing secara khusus siswa yang bersangkutan dan mejelaskan memberikan contoh sederhana.

Pada saat siswa membacakan atau melaporkan hasil karya atau RPP nya di depan kelas mensimulasikan dalam bentuk aktivitas belajar sehingga dapat diketahui apa problem yang dialami dalam pembelajaran, ide baru dan

Ketika guru meminta siswa memperbaiki RPP yang telah dibuat dan memberikakan pendapat dan kesannya terhadap kegiatan yang dilakukannya ada mahasiswa yang tidak berani berbicara sehingga dosen seharusnya perlu memberikan penguatan kepada mahasiswa tersebut.

Upaya pemahaman hasil kemampuan siswa terhadap menulis puisi yang dilakukan oleh guru cukup baik, hal ini sangat bermanfaat bagi siswa dalam mengukur kemampuan belajar menulis puisi bagi siswa.

Berdasarkan hasil pengamatan guru pada kegiatan tahap pramenulis pada siklus I ini maka kemampuan mahasiswa dapat diklasifikasikan sebagai berikut; siswa yang dikategorikan memperoleh nilai sangat baik (SB) adalah sebanyak 2 mahasiswa, baik (B) sebanyak 2 mahasiswa, cukup (C) sebanyak 3 mahasiswa, kurang (K) sebanyak 2 mahasiswa.

\section{Refleksi siklus II}

Tujuan pembelajaran disampaikan dengan jelas oleh dosen. Melalui kegiatan parodi siswa menyanyikan lagu dan setiap mahasiswa memparodikan struktur RPP yang telah diajarkan pada siklus pertama,

Pada kegiatan Tanya jawab antara guru dengan siswa, pertanyaan-peratanyaan pembangun pengetahuan awal siswa yang diajukan tidak merasa kesulitan untuk menjawab karena mahasiswa telah memahami tentang unsur-unsur atau struktur dalam menyusun RPP.

Ketika dosen mengondisikan mahasiswa duduk dalam kelompok seperti yang dilakukan pada tindakan siklus, dengan cepat siswa menempatkan diri duduk sesuai kelompok yang telah di bentuk sehingga dengan mudah guru 
mengarahkan untuk bekerjasama dalam berdiskusi dalam kelompoknya.

Setiap kelompok siswa ditugaskan dosen untuk melakukan wawancara dengan dosen masyarakat belajar melalui, menggunakan hasil pengamatannya sebagai ide/gagasan pokok. Dari obyak/benda yang diamati siswa menentukan judul puisinya serta dapat mengembangkannya sesuai unsur-unsur atau struktur yang ada dalam menyusun RPP, Akibatnya dalam kegiatan ini siswa menghasikan suatu karya yang utuh yang disebabkan oleh pemberian dorongan, pemusatan perhatian,penggalian informasi, pemecahan masalah, pengecekan pemahan yang selalu di berikan oleh dosen pada siswa saaat melakukan kegiatan.

Dosen menyampaikan kesimpulan kepada mahasiswa terhadap materi perkuliahan bersama mahasiswa saling merefleksi kegiiatan pembelajaran, mana yang sudah dipahami dan mana yang belum dipahami, selanjutnya bersama sama menyusun rencana tindak lanjut untuk saling memberikan masukan terhadap RPP yang telah dilakukan.

Selanjutnya dalam sebuah analogi bahwa menyusun sebuah RPP seperti menyusun sebuah peta perjalanan yang apabila kita benar menyusun sebuah peta tersebut maka kita akan sampai pada tujuan yang akan kita capai walaupun banyak peta yang dibuat, dalam kegiatan kesan dan pesan pembelajaran siswa dibagikanlah sebuah apresiasi kepada mahasiswa bahwa kita sudah menuntaskan sebuah perjuangan besar tentang sebuah perencanaan.

\section{Hasil perubahan (kemajuan)}

Pada faktor guru keberhasilan tindakan adalah $43,33 \%$ atau atau berada pada kualifilasi baik (B). Adapun faktor keberhasilan tindakan siswa adalah 41,85\% atau berada pada kualifikasi baik (B).

Pada dua belas deskriptor proses menulis puisi yang dicapai guru adalah 39,33\% atau berada pada kualifikasi baik (B) dan yang dicapai siswa adalah $42,87 \%$ atau berada pada kualifikasi baik(B).

Pada faktor guru dari empat deskriptor yang ada maka keberhasilan yang diperoleh guru adalah $47,50 \%$ atau berada pada kualifikasi sangat baik (SB) dan yang di peroleh siswa adalah $44,81 \%$ atau berada pada kualifikasi sangat baik (SB).

Berdasarkan hasil tindakan pada tahap-tahap menulis maka kemampuan siswa seluruhnya adalah rata-rata $22,22 \%$.

\section{SIMPULAN}

Dari hasil penelitian pembahasan tentang kreativitas dalam mendesain RPP K-13 menggunakan pendekataan kontekstual dapat disimpulkan bahwa mahasiswa mampu menyusun RPP dengan pendekatan CTL walaupun semula siswa merasa kesulitan,namun adanya bimbingan dan pemberian model yang ditujukan dosen mahasiswa merasa mudah mengatasi kesulitan yang dialaminya dalam pemahaman unsur dan struktur dalam menyusun RPP.

Peningkatan keterampilan menyusun RPP tampak bahwa mahasiswa sudah mampu mendesain RPP dengan memanfaatkan kegiatan alfa zone, apersepsi dan multi strategi dalam pembelajaran mahasiswa tidak susah lagi dalam menyusun RPP karena mahasiswa sudah mampu mengembangkan indikator dalam memilih strategi yang cocok disesuaikan dengan konsep dan kondisi sishwa yang pada kelas yang dimaksud.

Peningkatan keterampilan menyusun RPP pada tahap pasca menyusun terfokus pada kegiatan catatan guru, moment spesial dan problem mengajar semua itu dicatat untuk memperbaiki proses pembelajara jyang berikutnya agar menjadi lebih baik.

Dari hasil penelitian dapat disampaikan saran sebagai berikut: (1) Disarankan kepada para guru dan mahasiswa agar menghindari kegiatan copy paste buku guru dalam menyusun RPP agar menggunakan multi strategi mengajar agar RPP dapat disesuaikan dengan kondisi siswa dalam kelas dan didapatkan hasil belajar yang memuaskan, (2) Disarankan kepada guru sebelum mengajarkan RPP yang dibuatnya mengkonsultasikan dengan orang lain yang bisa memberkikan saran kritik atas RPP yang dibuatnya untuk diadakan revisi yang lebih baik, (3) Disarankan bahwa kendala-kedala yang ada jangan dijadikan patokan untuk tidak 
berusaha tetapi jadikanlah sebagai awal melaksanaka pembelajaran yang inovatif,

\section{DAFTAR PUSTAKA}

Alwi Hasal, dkk. 2000. Kamus Besar Bahasa Indonesia. Jakarta: Depdiknas.

Arikunto, Suharsimi. dkk. 2008. Penelitian Tindakan Kelas. Jakarta. Bumi Aksara.

Nurhadi, dkk. 2004. Pembelajaran Kontekstual dan Penerapan Dalam $K B K$. Malang. Universitas Negeri Malang.

Sanjaya, Wina. 2006. Strategi Pembelajaran: Berorientasi Standar Proses Pendidikan. Bandung. Kencana Perdana Media Group.

Sulistyorini. S. 2007. Model Pembelajaran IPA Sekolah Dasa dan Penerapanya Dalam KTSP. Semarang. Tiarawaksana.

Trianto. 2007. Model-Model Pembelajaran Inovativ Berorientasi Kontruktvistik. Surabaya. Prestasi Pustaka Publisher.

Amri, Sofan (2018). Pengembangan \& Model Pembelajaran dalam kurikulum 2018. Jakarta : Prestasi Pustaka.

Arikunto, Suharsimi. 2010. Prosedur Penelitian Suatu Pendekatan Praktik. Jakarta: PT Rineka Cipta.

Baharudin. (2008). Pendidikan dan Psikologi Perkembangan. Yogyakarta: Ar-Ruzz sehingga kreativitas menyusun RPP dapat ditingkatkan.

Chatib, Munif. Sekolah Para Juara: Menerapkan Multiple Intelegence di Dunia Pendidikan, terj. Yudhi, Murtanto. Bandung:

Kaifa 2011 Intelligence.United States of America : MediaLink Associates, Inc.

Yohanes, Budinryanta. (2014). Membangun Budaya Literasi. Proseding Seminar Nasional Plus " Membangun peradapan Generasi Emas melalui Literasi".

Yulianto, Bambang. (2008). Modelmodel Pembelajaran InovatifProgresif. Surabaya: Universitas Negeri Surabaya.

As"ari, A. R. 2014. Mengupayakan Pembelajaran yang Sesuai Tuntutan Kurikulum 2018. Makalah disajikan dalam Seminar Pendidikan di Pangkalan Bun, Kalimantan Tengah, Kerjasama dengan Dinas Pendidikan Kota Waringin Barat dan Universitas Palangkaraya, 27 September 2018.

Kemendikbud. 2018. Peraturan Menteri Pendidikan dan Kebudayaan No. 65 Tahun 2018 tentang Standar Proses. Jakarta: Kementerian Pendidikan dan Kebudaya. 